\title{
Green Technologies and Environmental Management: a New Understanding and Approach to the Use of Agricultural Waste
}

\author{
Faezeh Shirkhan ${ }^{1}\left(\mathbb{D}\right.$, Mahdieh Mostafidi ${ }^{1}{ }^{(\mathbb{D}}$, Maryam Tamaskani Zahedi ${ }^{1} \mathbb{D}$, Parisa Ziarati ${ }^{2, *}(\mathbb{D})$, Viola \\ Vambol ${ }^{3, *}$ (D), Sergij Vambol ${ }^{4}(\mathbb{D}$ \\ 1 Pharmacy and Pharmaceutical Sciences Faculty, Tehran Medical Sciences, Islamic Azad University, Tehran-Iran \\ 2 Department of Medicinal Chemistry, Pharmacy and Pharmaceutical Sciences Faculty, Tehran Medical Sciences, Islamic \\ Azad University, Tehran-Iran; ziarati.p@ iaups.ac.ir (P.Z.); \\ 3 Department of Applied Ecology and Environmental Sciences, National University «Yuri Kondratyuk Poltava \\ Polytechnic», Poltava, Ukraine; violavambol@gmail.com (V.V.); \\ 4 Department of Applied Ecology and Environmental Sciences, National University «Yuri Kondratyuk Poltava \\ Polytechnic», Poltava, Ukraine; sergvambol@gmail.com (S.V.); \\ * Correspondence: violavambol@gmail.com (V.V.); ziarati.p@iaups.ac.ir (P.Z.);
}

Received: 14.05.2021; Revised: 15.06.2021; Accepted: 18.06.2021; Published: 27.06.2021

\begin{abstract}
The waste from fruit and vegetable processing and also agricultural wastes contain valuable particles (antioxidants, dietary fibers, proteins, natural dyes, aromatics, adsorbent sites for removing toxins and contaminants) and, on the other hand, can be extracted, purified, and valorized in valueadded products. This is the basis for regaining the considerable potential of food waste, using it as a source of many green products, and opening up the possibility of their extraction and purification. It turns out that fruits and vegetables and roots and tubers have the highest rate of food waste. The FAO announced that global quantitative loss and waste of root crops, fruit, and vegetables is $40-50 \%$ per annum. Disposal of such quantities of waste is not only a challenge for food processors but is also a matter of key importance at the international level due to environmental pollution and economics. This is the right time to invite some disciplines and encourage the various industries to utilize chemistry and chemical engineering in the worldwide demand for environmentally friendly chemical processes by the new approach and insight into food waste. Contrarily food and agriculture biotechnology with a focus on sustainable food production can use living organisms to make useful products, with production carried out using microorganisms and natural substances from organisms. Bio-technologies in food production obligated effectively through application in the reclamation of wasteland by the deployment of microorganisms and plants to degrade toxic compounds; genetic modification in food, non-food crops; weed and pest control methods; minimized the consumption of energy and water in production processes to result in improved value-added activities and thus enhanced productivity.
\end{abstract}

Keywords: green foods; conservation of resources; food and agricultural waste; environmental safety; detoxification

(C) 2021 by the authors. This article is an open-access article distributed under the terms and conditions of the Creative Commons Attribution (CC BY) license (https://creativecommons.org/licenses/by/4.0/).

\section{Introduction}

The various stages of the food supply chain are produced, from farm to fork, including, thus, pre and post-consumer stages. Similarly, the term was used to denote a particular set of plant food wastes produced throughout the food supply chain (agricultural production, post- 
harvest transportation, storage) and consumer stage. In recent years, much attention has been devoted to developing its policies and methods of management. In general, waste management is "the collection, transportation, recovery, and disposal of waste, including the monitoring of such operations (2006/12/EC), and the waste management system includes "the whole set of activities related to work, disposal or disposal" [1-5]. One of the most important wastes is an agricultural waste issue in waste management in the whole world. Agricultural waste is a general term for organic matter disposed of by humans in the process of agricultural production. On the whole, we face too many organic materials in many states, such as wood and wood waste industries, agricultural residues, food wastes, food industries wastes, aquatic plants, and also algae which all could be play the main role as a substrate for $\mathrm{Bio}-\mathrm{H}_{2}$ products [6-9]. The enormous Bio-mass originated by agricultural residues, plant crops, and fruits, and woody biomass have been used to generate $\mathrm{Bio}-\mathrm{H}_{2}$ via both thermochemical and biological routes [1012].

It should be considered that making the organic division available for the bacteria, the cost of the integrated process due to the initial pre-treatment stage of requiring cellulose is still a challenge for obtaining cost-effective and competitive [13-19]. On the contrary of Cellulosic components, wastes enclose willingly applicable carbon, so constructing it as a very suitable favored substrate for Bio- $\mathrm{H}_{2}$ production. Dark fermentation mechanism fiercely practiced for Bio- $\mathrm{H}_{2}$ production due to more eco-friendly environmentally sustainable for less energy demanding. In figure 1 in the study [20] details the steps of the acidogenic fermentation process, generating volatile fatty acids and bio-hydrogen.

The use of waste as a natural resource for bioactive compounds in the food industry is shown in Figure 1 [21].

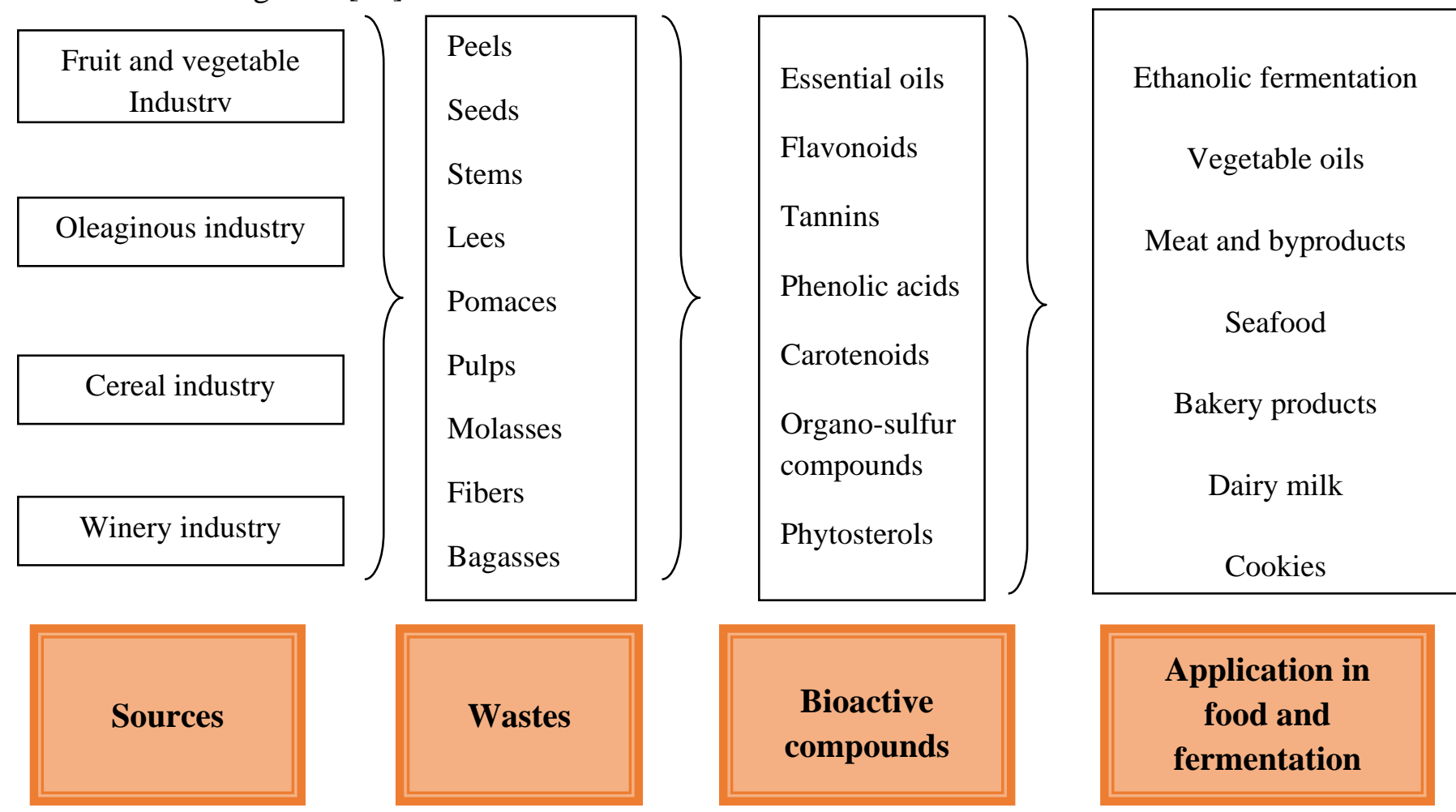

Figure 1. Use of agricultural and industrial wastes as a source for bioactive compounds.

\section{Materials and Methods}

This study documented the potential for food waste and its use as a source of many organic products. Relevant investigations were identified by searching PubMed and 
ScienceDirect. Scientific articles written in any language from 2010 to the present were considered. The two reviewers independently selected investigations, assessed their quality, and extracted data. In addition, additional publications identified by links in discovered publications were taken into account.

\section{Results and Discussion}

Nowadays, utilizing food waste in many industries is being concerned especially in modern countries.

\subsection{Results.}

\subsubsection{Production of bio-plastic through food waste.}

The definite economy for plastic packaging in many areas, which directly engender excessive carbon dioxide emissions and leakage into the environment, desires s to be renovated to a greener novel method that is Green Supplier Selection in New Era for Sustainability.

Among the various biodegradable plastic available, there is growing interest in the group of polymers known as poly-hydroxyalkanoate (PHA) [22-25]. The investigation by Ncube, L. K. et al. in 2020 is based on (i) Biodegradation of Bio-plastic with biological approaches (ii) Production of cost-effective Bio-plastic. The cost of bio-plastics serves as a hindrance to the development of Bio-plastics for food and drink packaging as the plastic is produced by harvesting the natural resources; thus, there is the utilization of the agricultural waste and reduces the overall cost of the product [26].

As in the face of petroleum-based plastic production, a huge sum of energy consumes the non-renewable sources that are depleted. Bio-plastic will be replacing the commercially conventional accessible plastic very soon. The degradable bio-plastic will reduces waste accumulation in the surrounding areas and environment. The most important characteristic of them would produce any toxic to the environment, and no harmful gas is emitted, thus no greenhouse gas and no global warming. This would be an environment-friendly product. Additionally, the implementation of a bio-refinery staging for food waste is an ideal option to pursue. If such a process is practically implemented, the cost of producing biodegradable plastics will likely be significantly lower compared to traditional production methods that use overpriced pure substrates (as glucose). The raw materials for the actual production of bioplastic from food wastes are present in nature [27]. Given the above, fermentation technologies based on pure and mixed cultures deserve special attention. In addition, it can be observed that a clear description of the chemical modification of cellulose, chitin, starch and caprolactone is reflected in a number of case studies, which also discuss promising approaches to assessing food waste and its economic/technical viability [28].

\subsubsection{Applications of agricultural waste.}

Use of Agricultural Waste and Compounds recovered from Food waste: Skin, meat, and grains can potentially be a good source for recovering bioactive compounds such as pectin, fats, flavonoids, dietary fibers, and more. A new bioremediation approach will aim to produce a wide range of valuable chemicals from food waste, especially agricultural waste [29,30].

The food waste, such as the fruit-processing industry, generates enormous solid waste in pomace, peels, kernels, and pulp following the industrial processing of fruit juices. The fruit 
residues are not only by industry products but are also found in the household kitchens, restaurant trash bins, hotel, juice, and local shops and contribute significantly to the municipal solid waste [31]. Due to economic issues and waste technology, by-products are receiving increased consideration by live-stock manufacturers, animal nutritionists, and bred animals, especially [31]. One of these products is apple pomace that is an alternative by-product obtained from apple juice industries in huge amounts and by fruit juice shops on another scale annually. The chemical composition of the final pomace is linked to the morphology of the original feedstock and the extraction technique used. According to NRC 2001, apple pomace (AP) in some regions is very low in protein (contains only $6.4 \%$ protein on a DM basis), and it also serves as a useful energy source for ruminants [15-18,29]. Other studies revealed that AP supplemented with natural protein was comparable to protein-enriched corn silage Ashwini et al. [32]. In contrast, the mean level of protein and mineral elements was determined from apple pomace, the fruits cultivated in Fars province in Iran showing much higher protein $(22.1 \%)$ and very high zinc, iron, and remarkable calcium contents [16]. In addition, much other food industry waste or agricultural wastes are used as bio-adsorbent for remediation of contaminant crops, vegetables, or cereals [33,34].

\subsubsection{Energy production from agricultural waste.}

Extraction processes mostly use waste as renewable sources for biofuel production [35]. However, fruits and vegetable by-products (FVW) are a very important class of residuals and wastes as they are produced in significant quantities from agricultural activities, supermarkets, and wholesale markets [36].

Biofuels are a renewable energy source and can therefore be used as an alternative to conventional fossil fuels. It burns up to $75 \%$ cleaner than fossil fuels. The use of noneconomical agricultural waste for biofuel production is a better way to utilize agricultural land. Sugar beet molasses, winter shells, rice husks, straw, maize, etc., are studied as biofuel production infrastructures. Biofuels are produced through contemporary biological processes, such as agriculture and anaerobic digestion, not fuel produced by geological processes. Biofuels are a wide range of fuels derived from biomass or plant material and animal waste as well as organic waste. Biofuels are also produced from industrial and municipal waste and forestry / agricultural wastes [37].

Methane gas can be produced from agricultural waste, especially fertilizers. This gas is suitable for heating purposes such as broiler factories, water heating, grain drying, etc. Anaerobic digestion of agricultural waste to produce methane-rich gas is a two-stage microbial fermentation. Initially, acid-forming bacteria break down volatile solids into organic acids used by eugenic methane organisms to produce methane-rich gas [38].

\subsubsection{Ethanol production from agricultural waste.}

In recent years, increasing research and development efforts have led to the commercial production of ethanol as the most promising biological fuel from renewable sources [39].

\subsubsection{Use of Agricultural Waste as a Food Additive.}

The use of fruit and vegetable waste products is highly regarded today, one of which can be as food additives (antimicrobial, antioxidant, pigments, flavors, and thickeners) [40]. 
3.1.6. Use of agricultural waste as a nutraceutical and functional foods.

Functional foods, nutrients, medical foods, and herbs are medicinal. Applied foods are those that provide scientifically proven specific health (health claims) beyond the form of nutrition. These include processed foods or foods containing health supplements such as adding iodine to salt or vitamin D to milk $[41,42]$.

\subsubsection{Pyrolysis.}

Greenhouse gas systems, agricultural waste are heated to $400-600{ }^{\circ} \mathrm{C}$ without oxygen to evaporate part of the material, leaving one character behind. This is a higher technology approach to using agricultural waste. Others are hydrolysis and hydrolysis. They are used to produce chemicals from agricultural waste as well as for energy recovery. Of particular interest are agriculture, the preparation of alcohol for fuel, ammonia for fertilizers, glucose for food and feed. Greenhouse gas emissions generate low-heat gasoline, fuel, and gas [38].

3.1.8. Use of agricultural waste as compos \& vermicompost.

Composting reduces the volume of waste, hence solving serious environmental problems related to the disposal of large quantities of waste, eliminating the pathogens present in it, reducing weed germination in agricultural fields, and reducing odor [43]. The benefits of recycling organic waste include improving soil texture and thus fertility, increasing crop productivity, and replacing agricultural chemicals. Recycling organic waste poses risks such as heavy metal toxicity, emerging contaminants, and ultimately food chain contamination.

3.1.9. Use of agricultural waste fibers.

Agricultural waste fiber has a high diversity in properties and depends on fiber structure, fiber cell dimension, microbial angle, and chemical composition. Some of the most important applications of fiber derived from agricultural waste are mentioned [44]: - Building component; - Furniture applications; - Automotive applications; - Medical applications; - Sporting goods; - Packaging applications.

3.1.10. Adsorbents in the elimination of heavy metals.

Due to industrialization and urbanization, too much heavy metal release into the environment has created a major problem worldwide. In recent years, that is the main reason that low-cost alternative agricultural and food industries' wastes have been considered to eliminate or significantly reduce toxic heavy metals from contaminated food and wastewater if used as bio-sorbents [45-54]. Agricultural waste has loose and porous structures and contains functional groups such as carboxyl and hydroxyl groups to be used as a bio-sorption material [16-18, 55]. The low-cost agricultural waste for the elimination of heavy metals from wastewater has been investigated by various researchers $[38,45-50,55]$.

\subsection{Discussion.}

3.2.1. Pollution from agricultural waste.

The potential wide-ranging environmental impacts of FLW (Reducing food loss and waste) impact climate, climate, and other land-related matters used for food production [56]. 
Food waste is an emerging environmental issue that contributes to increased greenhouse gas (GHG) emissions in landfills and impacts climate change [57]. When food is disposed of and disposed of in a landfill, it releases methane gas $\left(\mathrm{CH}_{4}\right)$, which traps heat in the atmosphere at a rate 21 times higher than carbon dioxide $\left(\mathrm{CO}_{2}\right)$. However, the production of $\mathrm{FW}$ methane/carbon footprint is dumped on energy/nutrient-dependent landfills. Water Pollution: FW dumped in landfills can be a source of nutrients and pathogens (through leachate and runoff) in waterways and groundwater contamination that can affect land and aquatic biodiversity. Impacts on water resources: FW is a major discharge on natural resources $[58,59]$. Agricultural waste refers to waste produced as a result of different agricultural operations. This includes fertilizer and other waste from farms, poultry and slaughterhouses, harvesting waste; fertilizer from farms; pesticides that enter the water, air, or soil [42]. Salt and salt are drained from the fields. Agricultural management is a complex process that draws people's attention to all functional components such as water, fertilizer, and dioxide. A significant limitation in agricultural waste management is the lack of information on different geographical areas. Therefore, there is an urgent need to establish a tangible mechanism for establishing an international database on agricultural waste's quantity, composition, and characteristics [60].

\subsubsection{Effects of agricultural waste on the environment.}

Soil and Water Pollution: Wastes generated from fruits and vegetables are organic and contribute a major share in soil and water pollution. Greenhouse gas emissions caused by fruit and vegetable wastes (FVWs) are a matter of serious environmental concern [61].

\subsubsection{Waste disposal and effects on the environment.}

The methods used for the disposal of agricultural waste are as significant a factor affecting the state of the environment as waste quantity since some disposal methods are very polluting. For example, the burning of agricultural waste is a powerful source of air pollution, common in undeveloped countries. Pollutants such as carbon monoxide, nitrous oxide, nitrogen dioxide and particles (smoke carbon) are released in large quantities into the atmosphere when agricultural waste is burned, which is also accompanied by the formation of ozone and nitric acid, hence contributing to acid deposition, thereby posing a risk to human and ecological health [62]. The burning of manure and straw will generate much harmful gas, smoke, and dust, seriously polluting our environment. Animal manure also contains many pathogens, parasite eggs, heavy metals and so on. Some agricultural residues have even been directly discharged into water, leading to serious aquatic environment contamination [63].

Waste disposal in general and agricultural waste disposal is a major challenge. The effects of uncontrolled waste disposal on the water body can be catastrophic. Agricultural development is closely linked to the development of fertilizers. Due to their chemical composition and raw materials, fertilizers can be pollutants of water and soil. Uncontrolled use of fertilizers without knowing the soil properties increases the risk of contamination. In intensified agricultural areas, blue streams are at risk, and pollution with heavy metals, nitrates, phosphates, pesticides, and polycyclic aromatic hydrocarbons is becoming a reality. Nitrate particularly poses a great danger and is highly pollutants of groundwater [64]. The Disposal methods result in various environmental problems, including offensive odors and pollution of water, soil, and air. In addition, because of their high moisture content and high degradability, 
uncontrolled disposal of fruit and vegetable waste likely not only releases greenhouse gases but also has a negative impact on the landfill in cities and towns [65].

\subsubsection{Organic waste, animal-produced, and effects on the environment.}

Organic waste, especially animal-produced manure, can significantly degrade soil, climate, and climate if not properly managed or untreated. The stagnant waste provides a means of transmitting the race of flies and diseases. Uncontrolled degradation of organic waste, odor gases as well as ammonia evaporation results in acid rain. Due to the intensification of animal production in a small area of land, there are many concerns:

- water quality caused by higher nitrogen and phosphorus loading;

- the smell and air quality are unpleasant due to the release of ammonia, methane, and nitrous oxide;

- soil quality due to loading of potassium and phosphorus [38].

\subsubsection{Production of fungal infections.}

Pathogens and antimicrobial compounds in agricultural waste: for example, pistachio waste is classified as agricultural waste, which, if not properly managed, contaminates the pistachio product with Aspergillus fungus and discharges it into the environment causing annoying odors and growth and proliferation of flies and if buried in pistachio gardens. The volatile substances in it cause damage to the root and consequently stop the growth of the plant. One of the suitable options for recycling agricultural waste such as pistachio peel is compost production. However, when a large volume of compost is used, it may have an adverse effect on plant germination [66].

\section{Conclusions}

Today, there is a general lack of accurate information and understanding of the extent of food waste in different areas - phases of the food value chain from farm to fork. Scale Food waste is complex across the food supply chain. It can have a huge impact on a number of different ways, such as agriculture, food security, economics, waste Use and management, environmental protection, and human health. Agricultural wastes can be a valuable resource for improving food security, but if left untreated, maintained, or disposed of properly, agricultural wastes are likely to contaminate the environment or even harm human health. This calls for increased public awareness of agricultural waste's benefits and potential dangers, especially in developing countries. Also, using new methods and assistance in solving the agricultural waste problem by government agencies can greatly help reduce pollution and improve the production cycle.

\section{Funding}

This research received no external funding.

\section{Acknowledgments}

Nutrition and Food Sciences Research Center, Tehran Medical Sciences, Islamic Azad University is gratefully acknowledged. 


\section{Conflicts of Interest}

The authors declare no conflict of interest.

\section{References}

1. Plazzotta, S.; Manzocco, L.; Nicoli, M.C. Fruit and vegetable waste management and the challenge of freshcut salad. Trends Food Sci. Technol. 2017, 63, 51-59, https://doi.org/10.1016/j.tifs.2017.02.013.

2. Ziarati, P.; Fatahi, A.; Jafarpour, A.; Luis, C.-R. Heavy Metal Removal from Edible Leafy Vegetable by Low Cost Novel Adsorbents: Hazelnut Shell. 2020, 4, 20039, https://doi.org/10.24262/jsd.4.2.20039.

3. Tajik, S.; Ziarati, P.; Cruz-Rodriguez, L. Coffee Waste as Novel Bio-Adsorbent: Detoxification of Nickel from Contaminated Soil and Coriandrum Sativum. Methods 2020, 38, 41, https://doi.org/10.47485/26932504.1019.

4. Tavakoli-Hosseinabady, B.; Ziarati, P.; Ballali, E.; Umachandran, K. Detoxification of heavy metals from leafy edible vegetables by agricultural waste: apricot pit shell. J Environ Anal Toxicol 2018, 8, 548, https://doi.org/10.4172/2161-0525.1000548.

5. Ziarati, P.; Far, B.F.; Mashayekhi, E.; Sawicka, B. Removing arsenic by food-processing waste (Zizyphus jujuba seeds) and study on its adsorptive properties. Technogenic and ecological safety 2019, 5, 62-70, https://doi.org/10.5281/zenodo.2604648.

6. Saratale, G.; Chen, S.-D.; Lo, Y.-C.; Saratale, R.; Chang, J.-S. Outlook of biohydrogen production from lignocellulosic feedstock using dark fermentation - A review. J. Sci. Ind. Res. 2008, 67.

7. Pose-Juan, E.; Igual, J.M.; Sánchez-Martín, M.J.; Rodríguez-Cruz, M.S. Influence of Herbicide Triasulfuron on Soil Microbial Community in an Unamended Soil and a Soil Amended with Organic Residues. Front. Microbiol. 2017, 8, 378, https://doi.org/10.3389/fmicb.2017.00378.

8. Ziarati, P.; Moslehishad, M.; Mohammad-Makki, F.M. Novel adsorption method for contaminated water by wild endemic almond: Amygdalus scoparia. Biosciences biotechnology research asia 2016, 13, 147-153, http://dx.doi.org/10.13005/bbra/2017.

9. Pourzare, A.; Ziarati, P.; Mousavi, Z.; Faraji, A.R. Removing Cadmium and Nickel Contents in Basil Cultivated in Pharmaceutical Effluent by chamomile (Matricaria chamomilla L.) Tea Residue. J Sci Discov 2017, 1, http://dx.doi.org/10.24262/jsd.1.1.17006.

10. Mohan, S.V.; Raghavulu, S.V.; Peri, D.; Sarma, P.N. Integrated function of microbial fuel cell (MFC) as bioelectrochemical treatment system associated with bioelectricity generation under higher substrate load. Biosensors Bioelectron. 2009, 24, 2021-2027, https://doi.org/10.1016/j.bios.2008.10.011.

11. Venkata Subhash, G.; Venkata Mohan, S. Deoiled algal cake as feedstock for dark fermentative biohydrogen production: An integrated biorefinery approach. IJHE 2014, 39, 9573-9579, https://doi.org/10.1016/j.ijhydene.2014.04.003.

12. Venkata Mohan, S. Harnessing of biohydrogen from wastewater treatment using mixed fermentative consortia: Process evaluation towards optimization. IJHE 2009, 34, 7460-7474, https://doi.org/10.1016/j.ijhydene.2009.05.062.

13. Sobhani, L.; Ziarati, P. Study on potential bio-adsorption of Tangerine peel in removal of heavy metals: $\mathrm{Pb}$, Cd and Ni of vegetable coriander. J Sci Discov 2017, 1. https://doi.org/10.24262/jsd.1.2.17020.

14. Ziarati, P.; Mohsenin Moshiri, I.; Sadeghi, P.; Mohammadi, S. Grape Pomace Flour (Vitis spp.) from Shiraz in South of Iran by High Trace Mineral Elements as Food Supplements. SciFed Drug Delivery Research Journal 2017.

15. Lahiji, F.A.S.; Ziarati, P.; Jafarpour, A. Potential of Rice Husk Biosorption in Reduction of Heavy Metals from Oryza sativa Rice. Biosciences Biotechnology Research Asia 2016, 13, 2231-2237, http://dx.doi.org/10.13005/bbra/2388.

16. Gholizadeh, E.; Ziarati, P. Remediation of contaminated rice farmlands soil and Oryza sativa rice product by apple pomace as adsorbent. Biosciences Biotechnology Research Asia 2016, 13, 2245.

17. Motaghi, M.; Ziarati, P. Adsorptive removal of cadmium and lead from oryza sativa rice by banana peel as bio-sorbent. Biomedical and Pharmacology Journal 2016, 9, 739-749, https://dx.doi.org/10.13005/bpj/998.

18. Razafsha, A.; Ziarati, P. Removal of heavy metals from Oryza sativa rice by sour lemon peel as bio-sorbent. Biomedical and Pharmacology Journal 2016, 9, 543-553, https://dx.doi.org/10.13005/bpj/971. 
19. Ziarati, P.; Kermanshah, A.; Moslehishad, M. Adsorption Heavy Metal from Contaminated Water, by Modified Shell of Wild Endemic Almonds: Amygdalus Lycioides and Amygdalus Wendelboi. Biosciences biotechnology research Asia 2015, 12, 2451-2457, http://dx.doi.org/10.13005/bbra/1923.

20. Amulya, K.; Dahiya, S.; Venkata Mohan, S. Chapter 19 - Building a Bio-Based Economy Through Waste Remediation: Innovation Towards Sustainable Future. In Bioremediation and Bioeconomy, Prasad, M.N.V., Ed. Elsevier: 2016; 497-521, https://doi.org/10.1016/B978-0-12-802830-8.00019-8.

21. Shirahigue, L.D.; Ceccato-Antonini, S.R. Agro-industrial wastes as sources of bioactive compounds for food and fermentation industries. Ciência Rural 2020, 50, https://doi.org/10.1590/0103-8478cr20190857.

22. Awasthi, A.; Govindan, K.; Gold, S. Multi-tier sustainable global supplier selection using a fuzzy AHPVIKOR based approach. Int. J. Product. Econ. 2018, 195, 106-117, https://doi.org/10.1016/j.ijpe.2017.10.013.

23. Torfi, F.; Farahani, R.Z.; Rezapour, S. Fuzzy AHP to determine the relative weights of evaluation criteria and Fuzzy TOPSIS to rank the alternatives. Applied Soft Computing 2010, 10, 520-528, https://doi.org/10.1016/j.asoc.2009.08.021.

24. Wu, M.Q.; Zhang, C.H.; Liu, X.N.; Fan, J.P. Green Supplier Selection Based on DEA Model in IntervalValued Pythagorean Fuzzy Environment. IEEE Access 2019, 7, 108001-108013, https://doi.org/10.1109/access.2019.2932770.

25. Zhao, R.; Liu, Y.; Zhang, N.; Huang, T. An optimization model for green supply chain management by using a big data analytic approach. Journal of Cleaner Production 2017, 142, 1085-1097, https://doi.org/10.1016/j.jclepro.2016.03.006.

26. Ncube, L.K.; Ude, A.U.; Ogunmuyiwa, E.N.; Zulkifli, R.; Beas, I.N. Environmental Impact of Food Packaging Materials: A Review of Contemporary Development from Conventional Plastics to Polylactic Acid Based Materials. Materials 2020, 13, https://doi.org/10.3390/ma13214994.

27. Shaghaleh, H.; Xu, X.; Wang, S. Current progress in production of biopolymeric materials based on cellulose, cellulose nanofibers, and cellulose derivatives. RSC advances 2018, 8(2), 825-842. https://doi.org/10.1039/C7RA11157F.

28. Tsang, Y.F.; Kumar, V.; Samadar, P.; Yang, Y.; Lee, J.; Ok, Y.S.; Song, H.; Kim, K.-H.; Kwon, E.E.; Jeon, Y.J. Production of bioplastic through food waste valorization. Environ. Int. 2019, 127, 625-644, https://doi.org/10.1016/j.envint.2019.03.076.

29. Oltjen, R.R.; Rumsey, T.S.; Fontenot, J.P.; Bovaid, K.P.; Priode, B.M. Supplementation of Apple Pomace with Nonprotein Nitrogen for Gestating Beef Cows. III. Metabolic Parameters. J. Anim. Sci. 1977, 45, 532542, https://doi.org/10.2527/jas1977.453532x.

30. Mueller, C. The regulatory status of medical foods and dietary supplements in the United States. Nutrition 1999, 15, 249-251, https://doi.org/10.1016/s0899-9007(98)00186-5.

31. Bovard, K.P.; Rumsey, T.S.; Oltjen, R.R.; Fontenot, J.P.; Priode, B.M. Supplementation of apple pomace with nonprotein nitrogen for gestating beef cows. II. Skeletal abnormalities of calves. J. Anim. Sci. 1977, 45, 523-531, https://doi.org/10.2527/jas1977.453523x.

32. Chintale Ashwini, G.; Kadam Vaishali, S.; Sakhare Ram, S.; Birajdar Ganesh, O.; Nalwad Digambar, N. Role of nutraceuticals in various diseases: A comprehensive review. Int. J. Res. Pharm. Chem 2013, 3, 290-299.

33. Ziarati, P.; Moradi, D.; Vambol, V. Bioadsorption of heavy metals from the pharmaceutical effluents, contaminated soils and water by food and agricultural waste: a short review. Labour protection problems in Ukraine 2020, 36, https://doi.org/10.36804/nndipbop.36-2.2020.3-7.

34. Gorgani, S.; Ziarati, P. Study on potential environmental adsorption of egg shells to removal of lead and cadmium from Oryza sativa rice. iau-tmuj 2020, 30, 155-166, https://doi.org/10.29252/iau.30.2.155.

35. Banerjee, J.; Singh, R.; Vijayaraghavan, R.; MacFarlane, D.; Patti, A.F.; Arora, A. Bioactives from fruit processing wastes: Green approaches to valuable chemicals. Food Chem. 2017, 225, 10-22, https://doi.org/10.1016/j.foodchem.2016.12.093.

36. Pavi, S.; Kramer, L.E.; Gomes, L.P.; Miranda, L.A.S. Biogas production from co-digestion of organic fraction of municipal solid waste and fruit and vegetable waste. Bioresour. Technol. 2017, 228, 362-367.

37. Gosavi, P.; Chaudhary, Y.; Durve-Gupta, A. Production of biofuel from fruits and vegetable wastes. Yeast 2004, 17.

38. Obi, F.O.; Ugwuishiwu, B.O.; Nwakaire, J.N. Agricultural waste concept, generation, utilization and management. Nigerian Journal of Technology 2016, 35, 957-964.

39. Arapoglou, D.; Varzakas, T.; Vlyssides, A.; Israilides, C. Ethanol production from potato peel waste (PPW). Waste management (New York, N.Y.) 2010, 30, 1898-1902, https://doi.org/10.1016/j.wasman.2010.04.017. 
40. Gowe, C. Review on Potential Use of Fruit and Vegetables By-Products as A Valuable Source of Natural Food Additives. IISTE-Food Science and Quality Managemen 2015, 45, 47-61.

41. Varzakas, T.; Zakynthinos, G.; Verpoort, F. Plant Food Residues as a Source of Nutraceuticals and Functional Foods. Foods 2016, 5, https://doi.org/10.3390/foods5040088.

42. Ziarati, P.; Namvar, S.; Sawicka, B. Heavy metals bio-adsorption by Hibiscus sabdariffa L. from contaminated water. Technogenic and ecological Safety 2018, 4, 22-32, https://doi.org/10.5281/zenodo.1244568.

43. Jakobsen, S.T. Aerobic decomposition of organic wastes 2. Value of compost as a fertilizer. Resources, Conservation and Recycling 1995, 13, 57-71, https://doi.org/10.1016/0921-3449(94)00015-W.

44. Dungani, R.; Karina, M.; Sulaeman, A.; Hermawan, D.; Hadiyane, A. Agricultural waste fibers towards sustainability and advanced utilization: a review. Asian Journal of Plant Sciences 2016, 15, 42-55.

45. Jallilian, Z.; Ziarati, P. High potential of Ferulago angulate (Schlecht) Boiss. in adsorption of heavy metals. Biomedical and Pharmacology Journal 2016, 9, 201-208.

46. Ziarati, P.; Jafari, A.; Amin, G. Potential of Echium ameonum Fisch \& Mey in Removing Heavy Metals from Pharmaceutical Effluent. Bioscience and Biotechnology Research Asia 2016, 13, https://doi.org/10.13005/bbra/2303.

47. Moghadam, R.; Ziarati, P. Reduction of Arsenic Content in Imported Polished Rice: Association of Cooking Method. J. Chem. Pharm. Res. 2016, 2016, 622-627.

48. Ziarati, P.; Zahirnejad, M.; Asgar Pahanh, J. The Efficiency of Bio-adsorption of Heavy Metals from Pharmaceutical Effluent by Rumex crispus L. Seed. Journal of Pharmaceutical \& Health Sciences 2017, 5, 231-243.

49. Ziarati, P.; Mohsenin Moshiri, I.; Sadeghi, P. Bio-adsorption of Heavy Metals from Aqueous Solutions by Natural and Modified Non-living Roots of Wild Scorzonera incisa DC. Journal of science discovery 2017, 11, 1-8, https://doi.org/10.24262/jsd.1.1.17010.

50. Ziarati, P.; Mostafidi, M.; Shirkhan, F.; Zahedi, M.T. Analysis of removal methods of toxic heavy metals using bio-absorbs. Technogenic and ecological safety 2018, 4, 62-76, https://doi.org/10.5281/zenodo.1402587.

51. Alimardan, M.; Ziarati, P.; Jafari Moghadam, R. Adsorption of heavy metal ions from contaminated soil by B. integerrima barberry. Biomedical \& Pharmacology Journal 2016, 9, 169-175.

52. Mehrarad, F.; Ziarati, P.; Mousavi, Z. Removing Heavy Metals from Pharmaceutical Effluent by Plarganium Grandiflorum. Biomedical and Pharmacology Journal 2016, 9, 151-161.

53. Shokri, F.; Ziarati, P.; Mousavi, Z. Removal of Selected Heavy Metals from Pharmaceutical Effluent by Aloe vera L. Biomedical and Pharmacology Journal 2016, 9, 705-713.

54. Ziarati, P.; Mostafidi, M.; Arabian, S. Patent № 138281 Ukraina, Sposib ochystky vody. Zayavka u201904687 2019.

55. Dai, Y.; Sun, Q.; Wang, W.; Lu, L.; Liu, M.; Li, J.; Yang, S.; Sun, Y.; Zhang, K.; Xu, J.; Zheng, W.; Hu, Z.; Yang, Y.; Gao, Y.; Chen, Y.; Zhang, X.; Gao, F.; Zhang, Y. Utilizations of agricultural waste as adsorbent for the removal of contaminants: A review. Chemosphere 2018, 211, 235-253, https://doi.org/10.1016/j.chemosphere.2018.06.179.

56. Muth, M.K.; Birney, C.; Cuéllar, A.; Finn, S.M.; Freeman, M.; Galloway, J.N.; Gee, I.; Gephart, J.; Jones, K.; Low, L.; Meyer, E.; Read, Q.; Smith, T.; Weitz, K.; Zoubek, S. A systems approach to assessing environmental and economic effects of food loss and waste interventions in the United States. ScTEn 2019, 685, 1240-1254, https://doi.org/10.1016/j.scitotenv.2019.06.230.

57. Thi, N.B.D.; Kumar, G.; Lin, C.-Y. An overview of food waste management in developing countries: Current status and future perspective. J. Environ. Manage. 2015, 157, 220-229, https://doi.org/10.1016/j.jenvman.2015.04.022.

58. Fao, G. Global food losses and food waste-Extent, causes and prevention. SAVE FOOD: An Initiative on Food Loss and Waste Reduction 2011.

59. Eriksson, M.; Spångberg, J. Carbon footprint and energy use of food waste management options for fresh fruit and vegetables from supermarkets. Waste management (New York, N.Y.) 2017, 60, 786-799, https://doi.org/10.1016/j.wasman.2017.01.008.

60. Nagendran, R. Agricultural Waste and Pollution. 2011, 341-355. Academic Press.

61. Panda, S.K.; Mishra, S.S.; Kayitesi, E.; Ray, R.C. Microbial-processing of fruit and vegetable wastes for production of vital enzymes and organic acids: Biotechnology and scopes. Environ. Res. 2016, 146, 161-172, https://doi.org/10.1016/j.envres.2015.12.035. 
62. Sabiiti, E.N. Utilising agricultural waste to enhance food security and conserve the environment. African journal of food, agriculture, nutrition and development 2011, 11.

63. Wang, B.; Dong, F.; Chen, M.; Zhu, J.; Tan, J.; Fu, X.; Wang, Y.; Chen, S. Advances in Recycling and Utilization of Agricultural Wastes in China: Based on Environmental Risk, Crucial Pathways, Influencing Factors, Policy Mechanism. Procedia Environmental Sciences 2016, 31, 12-17, https://doi.org/10.1016/j.proenv.2016.02.002.

64. Akinro, A.O.; Oloruntade, A.J.; Imoukhuede, O.B. Impacts of Agricultural Wastes on Groundwater Pollution in Lipakala Farms, Ondo Southwest Nigeria. Journal of Environment and Earth Science. Available Online: www. iiste. org. ISSN 2224-3216 (Paper) ISSN 2225-0948 (Online), 2, 2012.

65. Ji, C.; Kong, C.-X.; Mei, Z.-L.; Li, J. A Review of the Anaerobic Digestion of Fruit and Vegetable Waste. Appl. Biochem. Biotechnol. 2017, 183, https://doi.org/10.1007/s12010-017-2472-X.

66. Jalili, M.; Ebrahimi, A.; Karimi, H.; Mokhtari, M. Survey the Effect of Pistachio Waste Composting Process with Different Treatments on Concentration of Heavy Metals. SSUJ 2016, 15, 103-114. 